\title{
BETWEEN \\ POVERTY AND \\ THE PYRE
}

Moments in the history of widowhood

Edited by Jan Bremmer and

Lourens van den Bosch

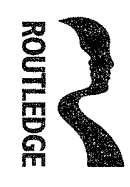

London and New York

1995 


\section{WIDOWS IN ANGLO-SAXON ENGLAND}

\section{Rolf H. Bremmer Jr}

For the early Middle Ages, no country in Western Europe can boast of such wide documentation as Anglo-Saxon England." One of the interesting aspects of its cultural history, which started with the Germanic invasions in the course of the fifth century and ended with the Norman Conquest in $\mathrm{AD} 1066$, is that it passed from a pagan Germanic into a Christian society. Studying the position of widows in this period, therefore, implies an awareness of two traditions which have often blended to a degree where it is impossible to distinguish them. Moreover, the nature of the available sources, varying from epic to sermon and law, and composed in different periods and places, should alert us to the danger of making a monolith picture of the Anglo-Saxon widow. We should also bear in mind that most of the extant documents were produced by and intended for the upper crust of a mainly illiterate society. Because of these restrictions, what we discover of the image of widows will necessarily be of a mixed nature. ${ }^{1}$

\section{TERMINOLOGY}

The Anglo-Saxons had two specific words for designating a woman whose husband had died. The more common one was widuwe and variants, a word with cognates in most of the other Germanic languages (but not in Scandinavian), in Slavonic, Prussian, Latin or Sanskrit - in other words, it belongs to the common lexicon of IndoEuropean. ${ }^{2}$ Like most other earlier stages of these languages, the Anglo-Saxon had no masculine form of widow, 'widower' in English being a neologism of the late fourteenth century. The absence of masculine forms in earlier times undoubtedly reveals that the woman as the one who had lost a partner was the marked person in society, whereas the widower was in a less vulnerable situation and freer to choose a new partner. His was not a recognized and permanent position. The other word used with some frequency for designating a widow is laf, literally 'what has been left behind'. ${ }^{3}$ It always occurs in the combination 'X's laf' and never in the generic sense. This term defines the widow in relation to her deceased husband. Thirdly, in certain contexts wif, 'woman who is not a virgin', can also mean 'widow', a conclusion which is corroborated by its being used to translate Latin vidua. ${ }^{4}$ A variety of words for designating a widow suggests that such a woman occupied a place of some conspicuousness in the social relations of the Anglo-Saxons. For a proper insight into the nature of that place, we will first turn to the laws.

\section{WIDOWS AND LEGISLATION}

Owing to a fairly large number of mainly vernacular codes of law that have survived, we are in a position to see at least how in legislation the position of women in general, but also of widows in particular, was defined. Notwithstanding these texts, we must bear in mind that what has come down to us in written law reveals perhaps only a fraction of the regulations that prevailed in daily life. Law was customary law, and on the whole only such rules as had actually resulted from jurisprudence were laid down in codes of law. ${ }^{5}$ As time passed, we can observe two main developments in the course of five centuries of legislative activities, often going hand in hand. The one is the growing importance of the king at the expense of the kindred, the other is the increasing influence of the church, apparent in the assimilation of, especially, canon law. ${ }^{6}$

The pillar of Germanic society was the kindred, and it was this form of social organization which the Anglo-Saxon tribes brought with them to Britain. In the cynn, or kindred, the males were formally responsible for the underaged and women. However much reality may have differed from theory, no woman could officially act without a legal guardian. Until her marriage, a woman remained under the protection (mund) of her father (or brothers); at her wedding she passed into that of her husband. Only as a widow would she be fairly independent, but her husband's kinsmen would still be legally responsible for the rights of her children. The laws of King Ine of Wessex (c. AD 690) state that a widow was to 'have her child and raise it'. She was to be given 'six shillings for its maintenance' as 
well as 'a cow in summer, an ox in winter' (Ine 38). Ine added to this provision that her husband's kinsmen were to act as the child's protector, 'to look after the parental home until he is grown up'. The contemporaneous laws of the Kentish Kings Hlothhere and Eadric specify the age of adulthood here as 10 years old. ${ }^{7}$ Remarkably, under the wergeld-system, which regulated financial compensation for injuries or death, she would still come under the responsibility of her paternal kin. ${ }^{8}$ Within this complicated division of legal obligations and regulations, a woman retained a certain amount of independence as a wife, resting on the material transactions that went along with a marriage. On his daughter's marriage, the father gave her property, usually land, as was agreed in the negotiations with the prospective husband. This was the dowry, which could alternatively be called wedd 'pledge' (the origin of the word 'wedding'); wituma, 'dowry'; gifu, 'present'; or federenfeoh, 'paternal fee'. The husband himself provided her with the morgengyfu, 'morning-gift', a substantial present of land and goods, the morning after the marriage had been consummated. ${ }^{9}$ Be Wifmannes Berweddunge, a document of the late tenth century describing the various steps leading to a legally contracted marriage, required the groom to declare before the bride's kinsmen, among other things, 'what he grants her in return for the acceptance of his suit, and what he grants her if she should live longer than he' (Wif 3). In other words, right from the outset of her marriage it had to be clear what the bride's dower amounted to. ${ }^{10}$

Occasionally, we are given a chance to see how such legal regulations were given shape in practice. Two marriage contracts survive, both from the early eleventh century, of which the contents make clear that the parties involved belonged to the élite. It is well worth quoting one of them:

Here in this document is stated the agreement which Wulfric and the archbishop [of York and Worcester] made when he obtained the archbishop's sister as his wife, namely he promised her the estates at Orleton and Ribbesford for her lifetime, and promised her that he would obtain the estate at Knightwick for her for three lives from the community at Winchcombe, and gave her the estate at Alton to grant and bestow upon whomsoever she pleased during her lifetime or at her death, as she preferred, and promised her 50 mancuses $[1$ mancus $=$ 30 silver pennies] of gold and 30 men and 30 horses. ${ }^{11}$

With such a start, the newly wedded wife would be certain to have considerable independence from her husband. She could freely spend the income of her morning-gift, while the dowry was added to her husband's property, albeit not always for good. If she became a widow, and had no children, the dowry would return to her paternal kin, to whom she would often move as well, while she remained still in control of the morning-gift herself. Several wills make clear that the husband could not bequeath property which had been given to her as her morning-gift, or they enumerate the estates that were given as such so as to prevent inheritance disputes. Ælfhelm's will, for example, contains such a clause: ${ }^{12}$

... and I declare what I gave to my wife as a morning-gift, namely, Buddow and Burstead and Stratford and the three hides ${ }^{13}$ at Enhale. And when we first came together, I gave her the two hides at Wilbraham, and Rayne and whatever pertains to it.

This will is exceptional because it mentions besides a morning-(after)gift a night-before present to encourage his designated wife to accept his suit. Frequently, too, the wills promise wives a substantial dower, or at least the usufruct of one or more estates. ${ }^{14}$ An instance of marital trust is found in the will of Ealdorman Ælfheah, which includes the provision: 'to my wife Ælfswith, if she live longer than I and maintains the property in accordance with the confidence I have in her, I grant all the other estates which I leave'. ${ }^{15}$ Such wives, once widowed, would not end up in the margin of society, but could continue to play a role of importance.

\section{THE ROYAL WIDOW}

Influential widows are indeed known to us, usually belonging to royalty, even though they sometimes receive nothing more than the barest mention in a chronicle, such as Queen Sexburh of whom it is said that she 'ruled for a year' after her husband, King Cenwalh of Wessex, had died. ${ }^{16}$ For a long time, the king's wife played a restricted role in Anglo-Saxon England, especially in the kingdom of Wessex. Bishop Asser, King Alfred the Great's (AD 852-99) biographer, suggested that the modest role assigned to them originated in the reputedly outrageous behaviour of King Beorhtric's wife, Eadburh. ${ }^{17}$ As soon as this Mercian princess had been married to Beorhtric of Wessex (c. AD 800), according to Asser, she began to reveal a behaviour similar to that of her father, King Offa, by plotting 
and scheming and disposing of those who did not obey her wishes. Eventually, Eadburh poisoned her husband, who accidentally drank from the wrong cup. Forced into exile to France, the royal widow visited Charlemagne, who presented her with a nunnery. But even as an abbess in such holy surroundings, she could not hide her true character. Caught in bed with a compatriot, she had to end her life as a beggar in Pavia.

More successful was the career of Æ£thelfled, King Alfred's daughter. Married to Ealdorman Æthelred of Mercia, in an attempt to tighten the bonds between Wessex and Mercia, she proved an able wife. During her twenty-year marriage, she actively participated in the administration of Mercia and helped her husband in recovering land from the Scandinavian invaders. Contemporary chroniclers refer to them as 'Lord and Lady of the Mercians', even as 'Lords' (blafordas), the male term. After her husband's death in AD 910, Ethelfled ruled Mercia single-handedly for another nine years. In effect, she had practically done so even before her widowhood, as her husband had been sickly for a good many years. Æthelfled ordered fortresses to be built, organized punitive expeditions into Wales and recaptured Derby from the Vikings. Upon her death, an Irish annalist reported that 'her fame spread abroad in every direction', an indication of the exceptional position she had held in the political constellation of England at the time. ${ }^{18}$

Royal widows seem to have been coveted partners more than once and for more than one reason. Such a marriage would enable the new king to buy off the lady's faction. If she were a foreign princess, the new marriage would continue the links with her home country. Marrying the dowager queen would also contain an element of legitimation. ${ }^{19}$ One could add to these arguments that such a union would secure a continuance factor in the passing on of royal authority. Several examples of such marriages from the Germanic world are known to us. Paul the Deacon reports two of them: ${ }^{20}$ Agilulf marries Theudelinda, widow of Authari, his maternal kinsman (mother's brother?) and becomes king. Interestingly, Paul has Theudelinda take the initiative for this marriage (Bk III, ch. 35). A gruesome story is Queen Rosemund's: a captive of war, she is married by the victorious Lombard King Alboin, who had killed her father, King of the Gepidae, and whose skull he had made into a goblet. Scarcely has she avenged her father, when she intends to marry Alboin's murderer Helmigis. When she wants to dispose of the latter in favour of yet another man, she offers him a poisoned drink. Helmigis drinks it, but then perceives her intentions and forces Rosemund to swallow the dregs, so that the two die together (Bk II, ch. 29). For the Suevi, chroniclers report that Audeca usurped the throne and took Siseguntia, the former King Miro's widow and his own mother-in-law, to wife, as he had already married Miro's daughter!21 The daughter apparently was only a stepping stone on his way to the Suevian throne. Especially famous through Shakespeare's Hamlet is the episode in Saxo Grammaticus's History of The Danes ${ }^{22}$ in which Fengi kills his brother King Orvendil and marries the latter's widow Gerutha - 'adding incest to fratricide' is Saxo's clerical comment (Bk III, ch. 77).

This type of marriage seems to have been concluded also in pagan Anglo-Saxon England. When Eadbald, son of the first Christian king of Kent, Ethelbert, ascended to the throne in AD 616, the AngloSaxon Chronicle drily recorded that 'he abandoned his baptismal faith and lived by heathen customs, so that he had his father's widow as wife'. The phraseology 'heathen custom', used by the chronicler around $\mathrm{AD} 900$, suggests an intimate knowledge of Anglo-Saxon pagan mores of three centuries earlier, which is not very likely. He may have had in mind the practice of his contemporary Germanic pagans, more precisely, those of the Scandinavian settlers in England. More probably, we need not interpret 'heathen custom' as Germanic, but rather as the traditional terminology, adopted from the church fathers, to condemn any practice which was not Christian. Bede's was a more emotional reaction, when he wrote in his Historia Ecclesiastica $(H E)$ that Eadbald 'was guilty of such fornication as the Apostle Paul [1 Cor. 5:1] mentions as being unheard of even among the heathen, in that he took his father's wife as his own' (Bk II, ch. 5). ${ }^{23}$ We are not told whether the queen approved of her new husband, who would have been her stepson. Nor did Eadbald take much pleasure from the union, as Bede hastens to inform his readers: 'This apostate king did not escape the scourge of God's punishment, for he was subject to frequent fits of insanity and possessed by an evil spirit.'

Was the practice of marrying one's father's widow really pagan only, as the chronicler would like us to believe? Almost 250 years after Eadbald, Charles the Bald gave his 12-year-old daughter Judith in marriage to King Æthelwulf of Wessex. Æthelwulf did not enjoy this marriage very long, for he died two years later, leaving behind a widow of $14 .{ }^{24}$ When his son Æthelbald succeeded him, Asser shows his abhorrence in saying: 
contrary to God's prohibition and Christian dignity, and also contrary to the practice of all pagans, [Æthelwulf] took over his father's marriage-bed, and married Judith, daughter of Charles, king of the Franks, incurring great disgrace from all who heard it. 25

The tone of indignation is paramount, and Asser was right in his condemnation of the liaison from a Christian point of view, as we shall see later. But his remark about the pagan practices in this respect is Pauline, flatly contradicting, as we have seen, the chronicler's opinion that such a practice was heathen. Judith may have played an active role in this marriage, judging by her later career. Again a widow, now at 17 , she returned to Francia, to elope with Baldwin, Count of Flanders, when she was about 19, and married for a third time. ${ }^{26}$ Twice a widow, and three weddings before her 21 st year might in Judith's case suggest something of the overdeveloped sexual appetite that widows were reputed to have, and feared for, especially in the later Middle Ages. ${ }^{27}$

Being twice the king's consort was also the lot of Emma of Normandy. First married to Ethelred the Unready, Emma later became the wife of Ethelred's fierce opponent and strategic superior, the first Danish king of all England, Cnut. Barely a year after Æthelred's death, 'the king [Cnut] ordered the widow of King Ethelred, Richard's daughter, to be fetched as his wife' (ASC s.a. 1017). Both marriages proved fruitful. From her marriage with Ethelred, her son Edward became king, from that with Cnut her son Harthacnut ascended the throne. The latter ruled from $\mathrm{AD}$ 1040-42, the former from AD 1042-66. Contemporary opinions of Emma are mixed, and certainly the sons bore few sentimental feelings towards their mother. When after Cnut's death in AD 1035, his son (by another woman) Harald Harefoot ascended to the throne, he had all the best treasures taken from her, which she could not keep back, which King Cnut had possessed (ASC C, s.a. 1035), and banished her to Bruges in $\mathrm{AD} 1037$. Upon his coronation in $\mathrm{AD}$ 1040 her son Harthacnut allowed her to come back, but only for a short time was she allowed to live in relative peace. Harthacnut ruled for just two years and was succeeded by his half-brother Edward the Confessor. One of Edward's first actions as king was the dispossession of his mother:

[He] deprived her of all the treasures which she owned, and which were beyond counting, because she had formerly been very hard to the king, her son, in that she did less for him than he wished both before he became king and afterwards as well. (ASC D, s.a. 1043$)^{28}$

However, Emma was allowed to live in Winchester, and she remained active there, as appears for example from her attesting to charters and wills until her death in 1051.29

Dowager queens naturally had a great interest in securing their position at the court. The lustre of that status is reflected, for example, by the signing habits of Queen Eadgyfu, widow of King Edward (AD 901-27). She proudly signed charters during the successive rules of her sons Edmund and Edred as 'mother of the king' (mater regis), and having outlived them, she added 'grandmother of the king' (ava regis) to her name when her grandsons had ascended to the throne. The position of the dowager queen was nevertheless precarious, as we have seen in Emma's case. Also Eadgyfu had to suffer being stripped of all her possessions by her grandson Edwig, but they were restored to her after Edwig's death by her other grandson, King Edgar. ${ }^{30}$ King Edgar's widow, Ælfthryth, earlier widow of Ethelwold, Ealdorman of East Anglia, was reputed to have killed her stepson Edward ('The Martyr') to clear the way for her own son Æthelred ('The Unready'). ${ }^{31}$ To her credit, her grandson Æthelstan the Ætheling on more than one occasion refers to her as ' $m y$ grandmother, who brought me up'..$^{32}$ Incidentally, this is the only indication we have for the period that grannies were employed (and appreciated) as babushkas!

For the epic Beowulf, it has been suggested that Beowulf married Queen Hygd, after her husband had died during a raiding campaign in Frisia, but the poem is not explicit on this matter. In fact the young Hygd offers Beowulf 'the hoard and the kingdom, rings and the royal throne; she did not feel her child [Heardred] could defend the ancestral seats of the kingdom against the peoples of other lands after the death of Hygelac' (Beow 2369-2372). Remarkably, the poet sees no problem in assigning to Hygd the active part of settling the question of succession to the throne. Hygd's solution comes tantalizingly close to offering her hand as well. Beowulf, however, declines the offer but is content to assume the role of Heardred's regent. Only after Heardred's fall in battle does Beowulf ascend to the throne. When violent death has overtaken Beowulf himself, the poem pictures his funeral obsequies, which include an old woman mourning with unbound hair at the funeral pyre. Some critics have 
identified her with Queen Hygd and made her into Beowulf's widow. The relevant passage in the manuscript, though, is badly damaged and as many emendations have been suggested as there are critical opinions. ${ }^{33}$ Should the old woman really have been Beowulf's widow, the scene would be the only description we have of a widow performing the funeral rites in an Anglo-Saxon, Germanic setting.

\section{WIDOWS OF LOWER RANK}

Quite naturally, the fortunes and misfortunes of widows at the top attracted due attention from the society reporters of the day, the chroniclers. It is mainly wills and charters that allow us to glimpse their sisters of lower ranks and how they strove to maintain their positions. When injured in their material interest, they would appeal to court, and sometimes, if needs be, they had recourse to violence, sometimes to fraud. A certain estate at Snodland in Kent had been bequeathed to the bishop of Rochester by a woman called Æscwyn. Her son $Æ$ lfric begrudged this pious act and paid a priest to steal the title deeds from the bishop. When the bishop discovered the theft, Ælfric had died in the meantime. His widow, apparently accomplice to the crime, was forced to appear at a court meeting in the presence of King Edgar (c. AD 975) to deliver the stolen deeds. She saw her property - estates at Bromley and Fawkham - forfeited which thereby legally fell to the king. The widow also gave up the title deeds of these estates, which were then bought by the bishop, who generously allowed her the usufructs of them, thereby showing his Christian concern for her as a widow. ${ }^{34}$

The events as described in a charter drafted during Æthelred the Unready's reign (AD 978-1016) are quite complicated. After his father's death, a certain Wulfbold had gone to his stepmother's estate, and 'took everything he could find there, inside and out, small and great'. He was repeatedly ordered by the king to give up what he had seized, but failed to appear, and each time he was condemned to pay his wergeld ${ }^{35}$ to the king. Finally, a great assembly, consisting of both ecclesiastic dignitaries and noblemen, was held at London, and Wulfbold's property was declared forfeit. Whatever he did, Wulfbold did not pay his fines until he died. And after his death, 'over and above all this', the charter indignantly continues, his widow together with her son went and killed Eadmer, her husband's brother's son, together with Eadmer's fifteen companions on an estate which Wulfbold had seized from his brother Brihtmær. ${ }^{36}$ The charter vividly illustrates the precarious situation a widow could find herself in when her dower was seized from her and also to what extremes she would go to regain possession of it.

Not always would a widowed mother and her son close ranks. A remarkable case is given by an account of a shire-meeting held at Aylton, Herefordshire, during Cnut's reign. There Edwin, Enneawn's son, sued his own mother to gain the possession of two estates. When the bishop asked who would represent her - and from this question we may conclude that the nameless mother is a widow - her kinsman Thorkil took it upon himself to defend her. Three men were sent to her to enquire about her defence. When she heard what was going on, she replied that she had no land to which her son had a proper claim. And then she grew so angry with her son that she called her kinswoman Leofflæd, Thorkil's wife, to her and made the following public statement:

Here sits Leofflæd, my kinswoman, to whom I grant both my land and my gold, and my raiment and my clothing and all that

I own after my death.

She did not leave it at that but told the messengers in an authoritative tone:

Behave as noblemen and do well; convey my message to the meeting before all the good men, and tell them to whom I have granted my land and all my possessions, and never one thing to my son; and ask them all to be witness to this.

Her request was indeed carried out, and Thorkil had her declaration confirmed by the meeting, and subsequently recorded in a gospel book in Hereford Cathedral, where it rests until the present day. ${ }^{37}$

As we have seen, the legal provisions were such that a widow could maintain a reasonably independent life. From documentary evidence like charters and wills, it becomes clear that we are dealing with widows belonging to the class of land-owning freemen. Rich widows were obviously popular candidates for spouses, and as often as not a widow may have longed for a man in the house. Remarriage was common, but there were certain restrictions imposed by the church. All later sources are unanimous in forbidding a widow to remarry within twelve months, an understandable measure as it had to be unambiguous that children born within this period were heirs to the property of her deceased husband. Ignoring the regulation resulted in her losing her morning-gift and all the goods which she had 
acquired through her former husband (II Cn 73). The new husband had to pay his wergeld as a fine to the king. If the proper period of twelve months had passed and she wanted to remarry, her paternal kinsmen were again involved in the negotiations (Wif 1). Having eligible women could be advantageous for a family, but several laws expressly state that a woman, whether a virgin or a widow, could not be forced to marry against her will (e.g. II Cn 74). Cnut also provided for abductions of widows with an eye to a marriage. Such an act would cost the abductor his wergeld (II Cn 52, 73-73.3), although the marriage could be allowed to stand. But even if a widow had been abducted and forced to marry, she would lose her properties if she refused to leave the new husband and return home. King Ethelred mentions the abduction of nuns and widows in one breath, and adds that the culprit should atone deeply for it 'both before God and the world' (VI Atr 39). An abducted nun who outlived her unwanted husband received nothing from the inheritance nor indeed did her children. If any of her children were killed, her share of the wergeld was to be paid to the king (Alf 8.1-3). Such severe provisions were no doubt intended for the nun to facilitate the choice between staying with her abductor or returning to the nunnery. A protecting influence may also have come from one of Cnut's codes which stated that the fine for raping or abducting a virgin was the same as that of raping a widow, viz. one wergeld (II Cn 52). The church was equally strict in such a case: rape or abduction of either a virgin or a widow, according to the Old English Penitential, resulted in excommunication. 38

Sometimes women were treated merely as pawns in men's games. The Beowulf poet tells of the sad career of the Danish princess Hildeburh who was married to Finn, King of the Frisians, in an attempt to establish peace between the two tribes. When her brother Hnaef came to visit Frisia the old feud was stirred up again, and after two fights interrupted by the winter, Hildeburh was brought back to Denmark, leaving behind the ashes of her husband, her brother and her son (Beow 1063-1159). 'That was a pitiful lady!' is how the poet summed up her fate. But the hard reality was also that widows could be pushed around. A Kentish charter of the late tenth century tells the fate of a number of estates, belonging to a certain Ælfheah, but granted, first to his brother Ælfric, and after the latter's death to Elfric's son Eadric. Eadric also died during Ælfheah's lifetime, 'leaving a widow and no children'. Ælfheah then resumed possession of his former estates, allowing the widow, however, to keep the estate
Eadric had given her as morning-gift. Before long, she had remarried a certain Leofsunu, who, 'on the strength of having married Eadric's widow', disregarded Ælfheah's will, and 'with his wife took possession of the estates'. ${ }^{39}$ Clearly, Leofsunu saw the widow as an opportunity to further his own interests. Also in national politics, widows were being taken advantage of for similar reasons. In the turbulent days of Æthelred the Unready, the chief thegns of the Five Boroughs, Morcar and Sigeferth, were treacherously killed by the king's party. The goods of these noblemen were confiscated and the king ordered Sigeferth's widow Ealdgyth to be caught and placed in a nunnery in Malmesbury. From there, Ethelred's obnoxious son Edmund Ironside abducted her and married her against the king's will. Love, though, was the last thing on Edmund's mind: late in August, he marched to the Five Boroughs and 'at once took possession of all of Sigeferth's estates and Morcar's, and the people all submitted to him' (ASC E, s.a. 1015). With Sigeferth's widow at his side, Edmund undoubtedly meant to emphasize his position as the new leader of the Five Boroughs.

\section{THE WIDOW-WITCH}

Occasionally, a widow's measures against those that threatened her were less directly violent, but by no means less malevolent. In a charter from the second half of the tenth century, the exchange of a number of estates is recorded between Wulfstan Uccea and Bishop Æthelwold. With respect to the estate at Ailsworth, the charter informs us how Wulfstan had acquired it:

A widow and her son had forfeited it, because they had driven iron pins into [an image of] Flfsige, Wulfstan's father. And that was discovered, and the death-bringing instrument was dragged from her chamber. Then the woman was taken and drowned at London Bridge, and her son broke away and became an outlaw.

The king confiscated her land, and donated it to her intended victim, who later bequeathed it to his son. ${ }^{40}$ We are not told why the widow had murder on her mind, but I think we are not far from the truth if we assume that she practised black magic to further her interests as a widow. Yet, one instance of a widow-witch from the period under investigation would be too slender for us to suppose that Anglo-Saxons associated widows with witchcraft. 


\section{ROLF H. BREMMER JR}

There are some indications, though, that such an association was in the air. Two sources from the generation immediately after the Norman Conquest, but dealing with the Anglo-Saxon period, provide further examples of widow-witches. William the Conqueror's occupation of the English throne did not go unopposed. Perhaps most famous was the resistance offered by the semi-legendary Hereward the Wake, who held the Isle of Ely in East Anglia from spring 1070 to autum 1071 against William. Driven to despair by Hereward's valiant defence, according to the early twelfth-century Gesta Herewardi, ${ }^{41}$ William even employs an old woman skilled in the art of black magic. As it happens, Hereward, having a scout around behind the enemy's lines disguised as a potter, spends the night at the house of a widow, who apparently provided bed and breakfast for her livelihood. Quite coincidentally, the other guest there is the witch who was hired by William. The two women converse in French, thinking that Hereward is unable to understand it. That night Hereward follows the witch and the widow, who proves to be an accomplice, to a spring where they seek advice of the spirit of the spring. Unfortunately, Hereward cannot hear what they are talking about. In the end, the witch pronounces her curses against Hereward and his men, bolstering her art by turning her bared arse (a very evil eye, indeed!) towards the island. Barely has she ended her act, when Hereward and his men set fire to the reeds that surround her, and she miserably ends her life there. ${ }^{42}$ Remarkably, the one witch in the story is old, ${ }^{43}$ while the other is explicitly referred to as a widow. Is it surprising to find the two together?

Supplied with fascinating details is William of Malmesbury's account of the witch of Berkely, to be found in his De Gestis Regum Anglorum, written in $1125 .{ }^{44}$ William describes her as a woman 'wellversed in witchcraft, not ignorant of ancient auguries, a patroness of gluttony, an arbiter of lasciviousness, not setting a limit to her debauches'. One day, her jackdaw forbodes great disaster, and indeed the news comes that her sons and other relatives have suddenly perished. She falls ill, and makes preparations for her imminent death. She asks her remaining children, a monk and a nun, to see to her burial as follows: they must sew her corpse up in a stag-skin, put it into a sarcophagus, sealed with lead and iron, and chained with three heavy chains. Her children are to sing psalms and masses for fifty days on end to secure her a safe conduct to the hereafter. But all these precautions are of no avail. The first two nights fierce devils appear, and snap a chain each time. The third night an even fiercer devil bursts in, breaks the last chain, pushes aside the stone lid, and takes the widow's corpse to where she belonged. In view of her adult children, it is clear that here, too, we are dealing with a woman who is well advanced in age, and as such fits in to a familiar pattern. ${ }^{45}$ Anthony Davies, in his interesting analysis of witches in Anglo-Saxon England, does much to play down the veracity of the witches in the Gesta Herewardi and William of Malmesbury's Gesta Regum. In particular, he considers William's witch to be an instance of 'fabrication'. ${ }^{46}$ If this were indeed the case, it would still leave us with the fact that three out of five known cases of witches in Anglo-Saxon England involve widows. That two of these three date from early postConquest sources may point to a growing marginalization of widows in English society.

\section{CHANGING PERSPECTIVES: THE CHURCH'S VIEW OF WIDOWS}

What we have seen so far concerns mostly the legal and social position of widows from a secular point of view. An important factor that would gradually change the way people looked at widows was the teaching of the church. Right from the early years of the conversion, the church saw itself confronted with customs that it could not tolerate. One of these was marrying spouses within certain degrees of kinship so as to avoid the risk of incest. ${ }^{47}$ In a long letter to Augustine, the first missionary from Rome, Pope Gregory the Great answered a number of questions which Augustine had presented him with (c. AD 600). One of his questions, according to Bede (HE Bk I, ch. 27), was: 'Is it lawful for a man to marry his stepmother or sister-in-law?' Gregory's answer on this matter was firm. Marrying one's stepmother he considered a great sin, for Moses's law said that 'Thou shalt not uncover the nakedness of thy father' (Lev. 18:8). Gregory must have realized that at first sight the logic of this precept was somewhat shaky. Therefore he added that married people had become one flesh, so that anyone who would marry his father's wife would uncover his nakedness, as he had been one flesh with her. Gregory's argument for prohibiting a marriage with a sister-in-law is based on other grounds. He might likewise have referred to Moses (Lev. 18:16), but instead Gregory mentions the fate of John the Baptist, who was beheaded for denouncing Herod's having married his brother's wife. John was a confessor of Christ, and Christ had said 'I am the Truth'. John died for the truth, 
ergo marrying one's sister-in-law was out of the question. While Gregory was lenient towards marrying relatives of the fourth degree onwards, in later times the church and, following its example, legislating kings likewise forbade marriage within the sixth degree (e.g. VI Atr $12 ; 1 \mathrm{Cn} 7$ ). Injunctions on trespassing were of the most drastic kind. The Old English Penitential (in the second half of the tenth century), a handbook assisting priests to define sins and to assign the appropriate penance, states that any man 'who marries his next of kin or his godmother or his brother's widow or his stepmother, let him be excommunicated from all Christian men'. If such a nan shows remorse, he must do penance for the rest of his life by the bishop's judgement. ${ }^{48}$ Some manuscripts containing a version of the Old English Penitential also include a report of a synod convened by Pope Gregory II at Rome in $\mathrm{AD}$ 721. In it, Gregory is reported to have said, among other things: ${ }^{49}$

'If any one has his own relative as a spouse or the widow of his next of kin, let him be excommunicated.' And all the bishops answered and said three times: 'Let him be excommunicated.'

We have seen in the cases of Kings Eadbald and Æthelbald that English royalty (then as now) tended to consider themselves above the law. Yet, both Bede's and Asser's strong reactions against these marriages show that the church's doctrine concerning the impermissibility of marrying widows of one's next of kin was embraced wholeheartedly by the clergy. .0

\section{COMMISERATION WITH WIDOWS}

In secular legislation, the Christian angle with respect to widows first becomes conspicuously clear in the long preamble to the laws of King Alfred the Great. Based particularly upon Exodus 20-22 and Matthew 5, Alfred includes the following statement on widows (Af El 34 ), merging the 'I' referring to God with his own:

Do not oppress the widows and the orphans, nor injure them. If you do nonetheless otherwise, they will call to me, and I will hear them, and I will strike you with my sword, and I will bring about that your wives will become widows and your children orphans. ${ }^{51}$

A similar admonition, this time directed specifically to the clergy, is found in the laws of Ethelred (VI Atr 46-8) to comfort and feed the poor, 'not to vex the widows and orphans too often, but to gladden them eagerly', and to desist from hurting strangers and those that have come from afar. The passage stems from Archbishop Wulfstan's pen and is also found almost verbatim in one of his sermons. ${ }^{52}$ In his sermon 'De Virginitate', Abbot Ælfric of Eynsham, the most prolific homilist of the period, tells his audience to give a third of the tithes to 'the poor, and widows, and orphans and foreigners', an instruction which also found its way into the laws of King Æthelred (VIII Atr 6). ${ }^{53}$ Another homilist, in a sermon on the Christian life, admonishes his audience to give alms daily, even as little as a quarter loaf in gratitude to God to beggars or widows or orphans or servants or foreigners' ${ }^{54}$ Obeying this precept was given the prospect of heavenly blessings, as could be illustrated by the examples of various pious men. Anglo-Saxon homilists could find an excellent case in the apocryphal Gospel of Matthew. In it, Ioachim, Anna's husband and Mary's father, serves as an exemplary house father: each year he divided the increase of his flock into three. One third he gave to 'the poor, and widows, and orphans and foreigners', a third to God's servants and one third he kept for his own household. God increased his possessions to such an extent that there was no man in Jerusalem as rich as him. ${ }^{55}$ In his sermons, Ælfric recurrently highlights almsgiving by biblical persons, and points out that Job was not boasting, but set an example to all men when he said: 'I delivered the crying poor, and I helped the orphan that was without support and I comforted the heart of the widow. ${ }^{56}$ Elsewhere, in a sermon on the Greater Litany, he adduces the witness of Isaiah, who exhorted the judges as follows: 'Help the oppressed, and judge orphans; defend the widow against cruel oppression, and rebuke me afterwards. ${ }^{57}$ In the epilogue to his sermon on the Maccabees, Ælfric includes an account of the High Priest Onias, who employed the gifts sent by King Seleucus 'to protect widows and orphans from hunger'. ${ }^{58}$

In Old English saints' lives, too, we recurrently meet the act of alms-giving to widows and other vulnerable members of society as an essential part of Christian life. On their missionary tour through Persia the apostles Simon and Jude had just converted a general, who very enthusiastically suggested burning all idolaters, who had plotted against the apostles, on a pyre. But no, said the apostles, we have come to preach life, not death. Christ taught us to love our enemies. Simon and Jude also declined the general's present of vast treasures, and urged instead if you want to make this money useful to your soul, distribute it to the poor and the sick, to widows and orphans 
and to destitute taxpayers[!] ${ }^{59}$ The apostle Thomas, too, entreated Gondophorus, King of the Indians: 'Let now your goods profit the widows, the poor and the sick, and know for sure that they will be kept for you a hundredfold.' ${ }^{60}$ St Lucy convinced her mother, herself a widow who for nine years had successfully managed her late husband's property, to sell her 'shining gems and even her landed property for ready money' in order to distribute it to 'the poor and to strangers, to widows and exiles and to the wise servants of God'. And to her wooer, 'an impious idolater', she retorted upon his invitation to sacrifice to his idols, that 'a pure offering, and acceptable to God, is that one should visit widows, comfort exiles and help orphans in their afflictions' . ${ }^{1}$ St Lawrence, at his bishop's command, distributed his church's treasures 'to priests, and poor strangers, and widows, to each according to his need'. ${ }^{62}$ Indeed, the faithful are told they will gain the glory of heaven by prayers and vigils and almsgiving, if you want to abandon all evil, both of manslaughter and perjury, and help widows and fatherless and motherless children, so that you may be called "God's children" with your brothers' ${ }^{63}$ By such virtuous examples and alluring prospects the clergy sought to influence the behaviour of their audience.

Kings, too, would hear how to behave properly, as in Ælfric's treatise De Duodecim Abusivis, where he advised the king: 'not to oppress with violence either the poor or the humble, but to judge each one justly. He must be a protector to the widows and orphans, suppress robbery, punish fornicators and expel the wicked from his realm.' 64 Note how the widows take preference in this enumeration of a king's moral duties. Occasionally, we are told of a king's concern for widows, as when Abbo of Fleury in his martyrdom of Edmund, the last king of the East Anglians, remarks that Edmund 'was generous towards the weak and the widows like a father'. ${ }^{65}$ Queen Eormenburh, widow of King Ecgfrith of Northumbria, 'was in all respects virtuous', because she honoured widows, orphans, the poor and crippled, 'unlike many people of noble birth today,' the author added in reproof, suggesting a cooling of the first love of the early years of Christianity in England. ${ }^{66}$

A genuine concern for widows also occupied Archbishop Wulfstan of York - who served as a legislator to both King Æthelred and his successor Cnut. In a thundering sermon composed and delivered in AD 1014, he pulls out all the stops of his rhetorical skills in painting a graphic picture of the social disintegration of the English people due to the continuing Viking raids. It is the English themselves who pile sin upon sin, and sacrilege upon sacrilege. Also 'widows have wrongfully been forced to marry, too many of them have been impoverished and greatly humiliated'. ${ }^{67}$ The precarious state of widows in social life was slightly earlier observed by a chronicler deprecatingly recording Ealdorman Ælfhere's opposition to the Benedictine Revival of the late tenth century. Elfhere 'broke God's law and hindered the monastic life, and destroyed monasteries and dispersed the monks ... and they plundered widows time and again' (ASC D 975). Elsewhere, Wulfstan complained about reeves, i.e. manorial officers, robbing widows over and over again. ${ }^{68}$

Now Archbishop Wulfstan may inveigh against such abominable deeds committed by laymen, but even bishops themselves were liable to neglect their pastoral duties towards widows. The tenth-century Blickling Homilies include a sermon which draws on the apocryphal Visio St Pauli. In that vision, an angel guides St Paul through Hell, explaining to him what sins the tormented souls have committed. Paul suddenly sees four angels leading a man with great cruelty to a fiery river into which he is sunk up to his knees and then bound with fiery chains. Upon his enquiring who this man is, the angel replies: ' $H$ e is a bishop who did more evil than good. Before the world he had a great name, but he disregarded all his duties as well as his Creator who had given him that office.' Paul inferred from this that the bishop had shown no mercy to either widows or orphans or any of God's poor, and commented that the bishop was rightly requited according to his deeds. ${ }^{69}$

Christian charity had probably been shown by prince Æthelstan, King Athelred the Unready's son, for in his will he mentions the money which Æthelwold's widow owed him and which he had paid 'for her help'. However much she will have been pleased at the time of the gesture, now she had to pay back the considerable amount of twelve pounds, as Ethelstan needed them for buying posthumous masses. Slavery was a hard reality in those days, a state into which people could transfer themselves if, for example, they were unable to pay their debts or if compelled by hunger. ${ }^{70}$ Paradoxically, slaveowning clergymen also had to propagate the church's preference for freeing slaves. A number of acts of manumission have come down to us, some of which mention widows. Godwig 'the Buck' redeemed Leofgife, a breadmaker, with her children for half a pound from her owner, Abbot Æilsige. Æilsige, in his turn, bought off Ongynethel and her son Gythiccael for a similar price. Marh freed his own slave Lethelt and her children by swearing on his private relics. Also 
widows spent money on freeing their less fortunate congeners. Edivu, Sxwgele's widow, bought Gladu for half a pound. Liueger, 'the female baker of Exeter', redeemed Edith and her children for thirty (silver) pennies from Bishop Gosfreige. Occasionally, we read of widows redeeming themselves, such as Edith, daughter of Leofric 'Curly-head' who paid four pounds and twenty pennies for her freedom and that of her children. Apparently on the occasion of a visit to Bath, paid for by King Eadred and Archbishop Æthelgar, two widows and their children as well as a man called Wurgustel and his children were set free. ${ }^{71}$

\section{THE CHASTE AND PIOUS WIDOW}

If some widows were poorly off - now an easy prey to plunder or bargained away to slave-traders, now a coveted candidate for a forced marriage - it is remarkable that the church did not encourage remarriage for pastoral reasons. Here, however, we see the high regard - some would say obsession - the church had for chastity. In fact, church fathers like Augustine, Jerome and Ambrose had divided the believers into three states or degrees of perfection: virgins, widows and the married, ${ }^{72}$ a division also taken up by the AngloSaxon theologian Aldhelm (c. AD 700) in his treatise De Virginitate. ${ }^{73}$ Elfric repeatedly mentions these three states in his sermons and letters, frequently in connection with the parable of the sower and the seed (Matt. 13:23). Virginity bears fruit a hundredfold, widowhood sixtyfold and wedded life thirtyfold. ${ }^{74}$ In his sermon on the wedding at Cana, Ælf ric refers to an expositor who said that the wedding-house was three-storied, 'because in God's church there are three degrees of chosen men', whereupon he enumerates the degrees. 75

Seen in the light of this concern for chastity, admonitions not to remarry become understandable. Whereas secular law knows of no limit to the number of marriages, the church discouraged remarriage. Ælfric does not tire of reminding his audience of this restriction, sometimes by appealing to St Paul. ${ }^{76}$ The Old English Penitential states that no Christian is allowed to marry more than twice, likewise with reference to Paul (although the apostle is not as explicit as medieval theologians would have it, cf. 1 Cor. 7:8-9). ${ }^{77}$ Moreover, the widow should be young when she remarries. According to the Canons, a remarriage should not receive the church's blessings, 'so as to make clear to them that it had been better for them to have remained chaste'.78 Archbishop Wulfstan wholeheartedly agreed with Abbot Ælfric: a priest should be absent from a second marriage to make the spouses feel that it was not quite right to remarry. But apparently, even Anglo-Saxon blood was thicker than water, for Wulfstan continues his argument by saying that it is 'certainly too much should it happen a third time, and completely wrong should it happen more often' ${ }^{79}$ The underlying thought is that marriage was the proper institute for sexual intercourse, and intercourse was only tolerated for procreation. So the older the candidate for a second marriage was, the more likely he or she was driven by other motives than procreation. In the words of Ælfric, 'it is very improper and shameful that worn out and impotent men desire marriage, because marriage is ordained for nothing but the procreation of children' ${ }^{80}$ Not only men were thus reproached by Ælfric. 'It is a shame and disgrace,' he wrote to Sigefyrth, 'that old women should have sex with men when they are worn out and too old for getting children, and a sign of inconstancy, for the sexes have been ordained for nothing else but for getting children only, as holy books teach us. ${ }^{.81}$ The call for chastity had some appeal to the reeve Abba. In his will, he promises his land to his wife should he die childless 'as long as she wants to keep it with chastity'. His brother Alchere is to be her guardian, in that case. If, however, 'she does not want to keep it with chastity, but prefers to conclude a second marriage', Abba's land is to go to his kinsmen while she can keep her own, that is, her morninggift. Yet Abba allows us to see that there are more options open to a widow than permanent widowhood or remarriage. He also foresees that his (nameless) wife might want to enter a monastery or even go on a pilgrimage to Rome. In that case his two brothers should pay her 2000 pence and get the land in return..$^{82}$

Widows were therefore urged to follow the example of such biblical widows as Judith or Anna. An anonymous poet recast the Book of Judith into an epic and, although the poem is open to more than one interpretation, chastity certainly plays a prominent role in it. Despite her being a widow, the poem calls Judith several times a 'virgin'. ${ }^{83}$ To Ælfric, Judith's story had more than one meaning. Her example should rouse the English to defend themselves courageously against the Scandinavian invaders, as he explained in an expository letter on the Old and New Testament to Sigwerd. ${ }^{84}$ Elsewhere, in the epilogue to his sermon on Judith, addressed to 'my sister', Elfric interprets Judith tropologically as a figure of Ecclesia, Christ's sole pure bride, who successfully defeated the devil (Holofernes). Moreover, many 
nuns should take example of this chaste widow of the old dispensation, Ælfric urged, while there are too many nuns, brides of Christ, who have not the slightest problem with fornicating here, there and everywhere. ${ }^{85}$ Wulfstan exhorts widows to follow the example of Anna in a way which is well worth quoting:

She was in the temple day and night diligently serving. She fasted greatly and attended prayers and called on Christ with mourning spirit, and distributed alms over and again, and ever propitiated God as far as she could by word and deed, and has now heavenly bliss for a reward. So shall a good widow obey her Lord. ${ }^{86}$

For the Anglo-Saxon homilist, the Bible provided more exemplary widows besides Anna. Best known is perhaps the hospitable widow of Zarephath who boarded Elijah (1 Kings 17), and who was also selected for praise by Jesus Christ (Luke 4:26). Men of God supported believing widows: Elijah restored the widow of Zarephath's son to life, ${ }^{87}$ Elisha saved a widow from her creditors (2 Kings 4 ), Jesus Christ resurrected the son of the widow of Nain (Luke 7:11-16), while Peter brought back to life Dorcas (a widow herself?) who had provided numerous widows of Joppa with garments (Acts 9:36-42)..$^{88}$ Such examples are reflected in the many saints' lives that circulated in Anglo-Saxon England. St John is reputed to have raised Drusiana in Ephesus, a widow 'of great faith, [who] gave much in alms, and the poor, whom she had bountifully fed, sad, with weeping, followed the corpse' ${ }^{89}$ St Lawrence healed a widow, called Quiriaca, of a troublesome migraine. During times of persecution under the emperor Decius, 'she had hidden in her dwelling priests and many lay Christians' ${ }^{90}$ Both St Maur and St Martin restored a widow's son to life, ${ }^{91}$ while through the intercession of St Clement a widow's son regained his life twelve months after drowning! ${ }^{92}$

Such miracles are not recorded for Anglo-Saxon widows or their sons, as far as I know. They had to make do with the sermons and saints' lives they would hear. Yet one should not get the impression that all widows occurring in such edifying texts behaved in an exemplary way. Occasionally we meet the exception to the rule such as the widow of a noble family from Cappadocia who had seven children. Raising those children appeared to be a burdensome task, and one day one of her children so infuriated her that she was driven to curse it. On her way to church she was persuaded by a devil in disguise not to curse just the one child but all seven of them. 'She then went to the baptismal font, unbound her hair, dipped it into the water, and with great fury sinfully cursed all her children.' Back home she came to her senses, and, conscience-stricken, hanged herself 'in the halter that she had spun with her feet'. ${ }^{93}$ Less sensational and more romantic was the plight of St Eugenia. As a young girl, she converted to Christianity, dressed as a man and, accompanied by two converted eunuchs, joined a monastery. She quickly made a career there and was elected abbot. Eugenia proved especially skilful as a physician, and on one occasion healed a woman called Melantia of a long-lasting fever. The woman - a widow, it appeared - was much charmed by the abbot's looks and qualities, and tried to win his favours, thinking all the time that the object of her affection was a young man. She called Eugenia home to her, feigning sickness, and then plainly made a proposal, telling her that she had been a widow for a year (so no restrictions in that respect!) and that her husband had endowed her well with land, cattle and servants. As her final trump card, she added that she and her husband had never had sex. So what would prevent the abbot from becoming her husband and lord? However much Melantia pleaded, Eugenia firmly resisted the temptation, until the widow in her frustration falsely accused the abbot of having assaulted her. To plead innocence Eugenia had to reveal her true identity and sex by baring her breasts before the judge. ${ }^{94}$ Luckily, the judge appeared to be her father(!), who had long been searching for his daughter. Melantia was spared on Eugenia's request, but Christ sent fire from heaven, which destroyed her house and all her property. In Eugenia's vita, then, a calculating widow is used to portray 'undisguised woman at her worst', contrasting with the 'de-sexed' Eugenia, the ideal woman as Ælfric saw her. ${ }^{95}$

Equally calculating, though perhaps taking a less frontal approach, was Earl Dolfin's widow. She fell in love with the previously mentioned Hereward the Wake, the rebel who withstood William the Conqueror, and openly sent messages to Hereward asking him to marry her, disregarding the fact that he was married already. Hereward was not averse to her overtures, nor did he remain cold under her charms. After all, 'there was nobody more lovely nor more beautiful in the realm, and scarcely anybody more eminent in their wealth'. Moreover, King William had promised her that if Hereward pledged faith with him he would not withhold his royal consent to the marriage. Beauty, wealth and peace made Hereward succumb to the deal, much to the disappointment of his wife, who thereupon 
'chose the better life' and became a nun. Hereward's selfish choice did not turn out to be a success, as from this point onwards his career would be increasingly beset by misfortune. .96

\section{PIOUS WIDOWS: SOME EXAMPLES}

The problem, one feels, with the picture of widows presented in homiletic discourse is that the ideal was too far removed from what was practically attainable. Were there no widows, then, in AngloSaxon England who lived a virtuous and pious life? Certainly, many widows took the veil, and especially noble widows often became abbesses of either nunneries or twin-monasteries. Cynethryth, King Offa of Mercia's widow, became Abbess of Cookham, her namesake Cynethryth, King Wiglaf of Mercia's widow, Abbess of Winchcombe. ${ }^{97}$ Eafe, King Athelwealh of Sussex's widow, was in charge of a monastery, as was Werburh, once Queen of the Mercians, according to the twelfth-century chronicler Simeon of Durham.98 Widows of lesser or unspecified rank, too, rose to the highest office: Ceolburg, widow of Ealdorman Æthelmund of the Hwicce, became Abbess of Berkeley; Dunne governed a monastery together with her daughter Bucge. ${ }^{99}$ St Mildreth joined the monastery which was headed by her mother, Queen Eormenburh. ${ }^{100}$ Ælfflæd assisted her mother Eanfled in governing the famous monastery of Whitby (Bede, HE Bk III, ch. 24 and Bk IV, ch. 26). Abbess Heriburg governed Watton, near Beverley, and counted her own daughter Coenburg among the nuns (Bede, $H E \mathrm{Bk} \mathrm{V}$, ch. 3); Wulfthryth (Wlfrid) was in charge of Wilton, outliving her saintly daughter Edith (Edgitha) in that monastery. ${ }^{101}$

The list no doubt can be augmented with many examples. Even married women could and did retire from wedded life and, as grass widows, entered the monastery. As Ælfrric wrote in a passage on matrimony: 'Separation is allowed to those who love exalted chastity more than anxious lust'. ${ }^{102}$ The most notorious case is Æthelthryth, who managed to preserve her virginity through two marriages, and finally received permission from her second husband, King Ecgfrith of Northumbria, to become Christ's bride (Bede, HE Bk IV, chs 19-20). She was first married to Tondberht, Ealdorman of the SouthGyrwas, who had given her the Isle of Ely as a dowry. The marriage lasted five years, after which she was a widow for an equal number of years. She must have been considerably older than Ecgfrith, whom she married when he was 15 . No matter how much land and money he offered her to get her into bed, Æthelthryth managed to resist his passes for twelve years, after which she took the veil. I myself am inclined to sympathize with Ecgfrith upon whom his wife forced celibacy from his 15 th to his 27 th year, but Bede exulted over the fact that she remained in 'virginitatis integritate gloriosa'. Ethelthryth later became Abbess of Ely which she had founded on her own property: the Isle of Ely had been given to her as her dowry by her first husband. 103

Other pious widows, outside the walls of the monastery, are harder to trace, but we may assume that they were around. The Old English translation of Theodulf of Orleans's capitulary takes for a fact that there are 'widows of such holy, pious life', that they can take the Eucharist daily, thus putting them on a par with monks. ${ }^{104}$ One such woman takes flesh and blood in Oswyn, a widow who frequented St Edmund's burial place with prayers and fasts. She was in the habit of trimming the saint's hair and nails each year 'with pure love'. 105

\section{RETROSPECT}

During the entire period, widows were an everyday phenomenon in society. The rate of mortality was high, not just for reasons of health, but also on account of violence. ${ }^{106}$ Legal provisions saw to it that the widow of the land-owning ranks had sufficient security to carry on living after her husband's death without anxiety for her livelihood or that of her children. In the Germanic tradition there were no restrictions on remarriage barring the commonsensical term of one year to prevent hereditary complications should the woman prove pregnant. However, in a pre-centralized society like that of AngloSaxon England, maintenance of the law still very much depended on the local community and the right of the strongest. Hence, the frequent cases we have seen of widows being deprived of their lands. Christianity brought a new order to marital life, and consequently, to that of widows. If limiting a widow's possibilities in choice and number of successive spouses, the church also opened up for her the road to a new career in the monastery. The church's emphasis on alms-giving to widows and the picture of widows as social underdogs undoubtedly stems from the Bible. Whether it tallied with everyday reality in Anglo-Saxon England is something for which I have found precious little corroborative evidence. The examples of pious widows we meet in the devotional writings of, especially, Ælf fric and Wulfstan are rarer to find in the reality of their day than those widows who 
opted for a less secluded, but more eventful life. As always, the distance between life and doctrine is hard to bridge.

\section{NOTES}

* My thanks are due to Christine Fell, Robin Smith, Derek Pearsall and Jan Bremmer for stylistic improvements and valuable suggestions.

1 A very informative introduction to women in general is C. Fell, Women in Anglo-Saxon England and the Impact of 1066 (London, 1984). Also relevant is a collection of new and older articles edited by $\mathrm{H}$. Damico and A.H. Olsen, New Readings on Women in Old English Literature (Bloomington and Indianapolis, 1990), and J.T. Rosenthal, 'Anglo-Saxon Attitudes: Men's Sources, Women's History', in idem (ed.), Medieval Women and the Sources of Medieval History (Athens, Ga. and London, 1990) 259-84, with a useful bibliography.

2 Cf. R.S.P. Beekes, 'Widow', Historische Sprachforschung 105 (1992) 171-87; for a more traditional view see, for example, W.P. Lehmann, $A$ Gothic Etymological Dictionary (Leiden, 1986) s.v. widuwo.

3 Nineteenth-century scholars would often use the now obsolescent word 'relict' as a translation of laf.

4 For example: Raptores... viduarum vel virginum is translated as Bepł 狈am men ze wif oððе moden ofernimp...., see J. Raith (ed.), Die altenglischen Version des Halitgar'schen Bussbuches (sog. Poenitentiale Pseudo-Ecgberti) (Darmstadt, 1964²) II, 13. Most of my research for this chapter is based on vernacular texts. I have greatly profited by A. diPaolo Healy and R.L. Venezky, A Microfiche Concordance to Old English (Toronto, 1980).

5 An outstanding introduction to Anglo-Saxon law is P. Wormald, 'Lex Scripta and Verbum Regis: Legislation and Germanic Kingship, from Euric to Cnut', in P.H. Sawyer and I.N. Wood (eds), Early Medieval Kingship (Leeds, 1977) 105-38; also informative is M.P. Richards and B.J. Stanfield, 'Concepts of Anglo-Saxon Women in the Laws', in Damico and Olsen, New Readings, 89-99. The classic edition of the Anglo-Saxon laws is F. Lieberman, Die Gesetze der Angelsachsen, 3 vols (Halle, 1903-16; repr. Aalen, 1960). All subsequent references to the laws are from this edition, with the usual abbreviations.

6 On the influence of the Church on secular legislation, see A.J. Franzen, The Literature of Penance in Anglo-Saxon England (New Brunswick, 1983) especially 125-7 and 146-8.

7 Cf. F. and J. Gies, Marriage and the Family in the Middle Ages (New York, 1987) $110 f$.

8 The Laws of King Æthelbert of Kent, issued c. AD 603, assigned special fines for trespasses against noble widows: 'The wergeld for widows of the highest rank, 50 shillings, that of the second rank, 20 shillings, that of the third, 12 shillings, that of the fourth, 7 shillings' (Abt 75).

9 This was common Germanic practice, cf., for example, K.F. Drew (tr.), The Lombard Laws (Philadelphia, 1973) 85 (Rothair 182), 147 (Liutprant 7); A.M. Lucas, Women in the Middle Ages: Religion, Marriage and
Letters (Brighton, 1983) 62f. For particulars concerning Anglo-Saxon England, see especially the index in Lieberman, Gesetze, vol. 2, s.v. Aussteuer, Eheschliessung, Frau, Vormund, Wittum, Witwe.

10 Cf. Gies, Marriage and the Family, 106.

11 A.J. Robertson, Anglo-Saxon Charters (Cambridge, 1939) no. LXXVI. The other marriage contract is Robertson, no. IXXVII.

12 D. Whitelock, Anglo-Saxon Wills (Cambridge, 1935) no. XIII; cf. her note on 135.

13 A 'hide' is an Anglo-Saxon surface measure, roughly a field large enough to maintain one family.

14 See, e.g., Robertson, Charters, nos III, VI, IX, XXVI and XXVII

15 Whitelock, Wills, no. IX.

16 C. Plummer (ed.), Two of the Saxon Chronicles Parallel, 2 vols (1892), reissued with a bibliographical note by D. Whitelock (Oxford, 1952); D. Whitelock, D.C. Douglas and S.I. Tucker (trs), The Anglo-Saxon Chronicle (London, 1961). The quotation, ASC s.a. 672, is quoted from Whitelock et al., as are all further quotations from the ASC.

17 Asser's Life of Alfred, chs 13-15, in S. Keynes and M. Lapidge (eds), Alfred the Great (Harmondsworth, 1983); cf. their note on 235f. On the position of the queen in Wessex, see P. Stafford, 'The King's Wife in Wessex, 800-1000', Past and Present 91 (1981) 3-27, repr. in Damico and Olsen, New Readings, 56-78. Unfortunately, Stafford's Queens, Concubines and Dowagers: The King's Wife in the Early Middle Ages (Athens, Ga., 1983) was not available to me.

18 On Æthelfled, see F.T. Wainwright, 'Æthelfled, Lady of the Mercians', in H.P.R. Finberg (ed.), Scandinavian England (Chichester, 1975) 305-24, repr. in Damico and Olsen, New Readings, 44-55; cf. R. Smith, 'Glimpses of Some Anglo-Saxon Women', in J. Dor (ed.), A Wyf there Was: Essays in Honour of Paule Mertens-Fonck (Liège, 1992, 256-63) 261-3.

19 P. Stafford, 'Sons and Mothers: Family Politics in the Early Middle Ages', in D. Baker (ed.), Medieval Women (Oxford, 1978, 79-100) 86.

20 W.D. Foulke (tr.), E. Peters (ed.), History of the Lombards (Philadelphia, $1977^{2}$ ).

21 Johannes Biclar, Chronica, J. Campos (ed.) (Madrid, 1960) s.a. 584; cf. Gregory of Tours, The History of the Franks, L. Thorpe (tr.) (Harmondsworth, 1974) Bk VI, ch. 43.

22 P. Fisher (tr.), H. Ellis Davidson (ed.), 2 vols (Cambridge and Totowa, N.J., 1979).

23 J.M. Wallace-Hadrill, Bede's 'Ecclesiasical History of the English People': A Historical Commentary (Oxford, 1988) 61, firmly states 'To marry one's father's widow was sound Germanic practice', but fails to give any supportive evidence. I only know of Radiger, son of the King of the Varni, who marries his father's widow at the behest of the father himself, who meaningfully adds 'just as our ancestral laws permit us'; see Procopius, De Bello Gothico, 7.20.20. Less Germanic, but in a similar vein to establish who is the new boss is Absalom's 'going in unto his father's [ten!] concubines in the sight of all Israel' (2 Sam. 16:22).

24 ASC s.a. 855-8; Asser, Life of Alfred, ch. 13. 
25 Asser, Life of Alfred, ch. 17.

26 Cf. Keynes and Lapidge, Alfred the Great, 238.

27 Cf. L.O. Vasvari, 'Why is Dona Endrina a Widow? 'Traditional Culture and Textuality in the Libro de Buen Amor', in L. Mirrer (ed.), Upon My Husband's Death: Widows in the Literature and Histories of Medieval Europe (Ann Arbor, 1992) 259-88; H.M. Arden, 'Grief, Widowhood and Women's Sexuality in Medieval French Literature', in Mirrer, Upon My Husband's Death, 305-20. The most notoriously nymphomaniac widow in later medieval English literature is, of course, Geoffrey Chaucer's Wife of Bath, who also married first when she was 12, outlived five husbands and was on the look-out for number six, cf. C. Wood, 'Three Chaucerian Widows: Tales of Innocence and Experience', in Dor, A Wyf ther Was, 282-90.

28 It seems that Emma had been involved in a plot against Edward, cf. Whitelock, Chronicle, 107 n. 8.

29 Cf. F.E. Harmer, Anglo-Saxon Writs (Manchester, 1952) 547.

30 Plummer, Two Saxon Chronicles, II, 134.

31 On this rumour, see especially C.E. Wright, The Cultivation of Saga in Anglo-Saxon England (Edinburgh, 1939) 146-53, 157-71.

32 Whitelock, Wills, nos IX, XV and XX; cf. Harmer, Writs, 551.

33 See most recently, H. Bennett, 'The Female Mourner at Beowulf's Funeral: Filling in the Blanks/Hearing the Spaces', Exemplaria 4 (1992) 35-50.

34 W. de Gray Bich, Cartularium Saxonicum (London, 1185-93) no. 1296, cf. Whitelock, Wills, $128 \mathrm{f}$

35 Wergeld, 'man-price', was the amount of money paid in compensation for killing a man. In Anglo-Saxon England one's wergeld depended on social rank.

36 The events are recorded in Robertson, Charters, no. LXIII and are discussed by H.R. Loyn, 'Kinship in Anglo-Saxon England', AngloSaxon England 3 (1974, 197-209) 201f. Internecine strife between paternal kinsmen was not uncommon in Anglo-Saxon England, particularly when property or the throne was involved, cf. R.H. Bremmer $\mathrm{Jr}$, 'The Importance of Kinship: Uncle and Nephew in Beowulf', Amsterdamer Beiträge zur älteren Germanistik 15 (1980, 21-38) 36-8.

37 Robertson, Charters, no. LXXVIII; cf. Fell, Anglo-Saxon Women, 78.

38 Raith, Bussbuch, II, 13. Old English did not always clearly distinguish in terminology between 'rape' and 'forceful abduction (to be married)', cf. H.H. Munske, Die germanische Rechtswortschatz im Bereich der Missetaten: I. Die Terminologie der älteren westgermanischen Rechtsquellen (Berlin and New York, 1973); see also B. Colman, 'Abduction of Women in Barbaric Law', Florilegium 5 (1983) 62-75.

39 Robertson, no. XLI, 11. 24-7.

40 On the practice of sympathetic magic, see A. Davies, 'Witches in AngloSaxon England: Five Case Histories', in D.S. Scragg (ed.), Superstition and Popular Medicine in Anglo-Saxon England (Manchester, 1989) $41-56$, at $49 f$.

41 Edited as Gesta Herewardi Incliti Exulis et Militis, appended to T.D. Hardy and C.T. Martin (eds), Lestoire des Engleis solum la translacion
Maistre Geffrei Gaimar, 2 vols (London, 1888-9) I, 339-404, at 385 and 389; part of the legend is to be found in another version in E.O. Blake (ed.), Liber Eliensis (London, 1962) Bk II, chs 102-7, at 183 and 186. The Gesta Herewardi are translated in M. Swanton (tr.), Three Lives of the Last Englishmen (New York and London, 1984).

42 The episode is well described by Davies, 'Witches', 41-3.

43 'anus illa venifica', Liber Eliensis, 183.

44 W. Stubbs (ed.), Willelmi Malmesbiriensis Monachi: De Gestis Regum Anglorum, 2 vols (London, 1887-9) I, 253-5.

45 On attributing witchcraft to old women, cf. J. Bremmer, "The Old Women of Ancient Greece', in J. Blok and P. Mason (eds), Sexual Asymmetry: Studies in Ancient Society (Amsterdam, 1987, 191-215) 204-6.

46 Davies, 'Witches', 45.

47 On the problem of incest, see M. de Jong, "To the Limits of Kinship: AntiIncest Legislation in the Early Medieval West (500-900)', in J. Bremmer (ed.), From Sappho to De Sade (London, 1989) 36-59.

48 Raith, Bussbuch, II, 18

49 Raith, Bussbuch, 72

50 Other references to this illicit union: A. Napier (ed.), Wulfstan: Sammlung der ibm zugeschriebenen Homilien nebst untersuchungen überibre Echtheit (Berlin, 1883) no. L, 271, 11. 8-12; no. LIX, 308, 11. 4-8. On this prohibition, of. P.J. Payer, Sex and the Penitentials: The Development of a Sexual Code: 550-1150 (Toronto, Buffalo and London, 1984) 32.

51 Cf. Exod. 22:22-4.

52 Napier, Wulfstan, no. LX, 309, 11. 1-5.

53 J.C. Pope (ed.), Homilies of Elfric: A Supplementary Collection, 2 vols (EETS OS) 259f. (London, 1967-8) II, no. XXX, 11. 96-8.

54 Napier, Wulfstan, no. XLVI, 238, 1.25-239,1.1. The sermon was wrongly attributed to Wulfstan.

55 Pseudo-Matthaei Evangelium, in B. Assmann (ed.), Angelsächsische Homilien und Heiligenleben (Kassel, 1889, repr. with a supplementary introduction by P. Clemoes, Darmstadt, 1964) no. X, 11. 45-60.

56 B. Thorpe (ed.), The Homilies of the Anglo-Saxon Church: The First Part, Containing the Sermones Catholici or Homilies of Alfric, 2 vols (London, 1844-6) I, 'Dominica I. in Mense Septembri, Quando Legitur Job’, 448, 11. 15-17.

57 Thorpe, Sermones Catbolici, II, 'Letania Maiore, Feria Secunda', 322, 11. 7-9.

58 W.W. Skeat (ed.), Alfric's Lives of Saints (EETS OS) 76, 82, 94, 114 (London, 1881-1900) III, no. XXV 'Passio Machabeorum', II. 254-5.

59 Thorpe, Sermones Catholici, II, 'Passio SS Simonis et Iude', 484, 11. 32-4.

60 Skeat, Alfric's Lives, IV, no. XXXVI, 'Passio Sancti Thomae Apostoli', 11. $192-4$.

61 Skeat, Elfric's Lives, I, no. IX, 'St Lucy, Virgin', 11. 53-6; 61-3.

62 Thorpe, Sermones Catholici, I, 'Passio Beati Laurentii Martyris', 418, Il. 16-18.

63 Napier, Wulfstan, no. XLV, 228, 11. 18-23. 
ROLF H. BREMMER JR

64 R. Morris (ed.), Old English Homilies (EETS OS) 29, 34 (London, 1868) Il. $296-304$

65 Skeat, Alfric's Lives, IV, no. XXXII, 1.22

66 M. Förster, 'Die altenglischen Beigaben des Lambeth-Psalters', Archiv für das Studium der neneren Sprachen und Literaturen $132(1914$ 328-35) 333f. The text dates from the second half of the eleventh century.

67 D. Bethurum (ed.), The Homilies of Wulfstan (Oxford, 1957) no. XX 11. 42f.; cf. D. Whitelock (ed.), Sermo Lupi ad Anglos (London, 1963³) 51 n. 42.

68 K. Jost, Die 'Institutes of Polity, Civil and Ecclesiastical': Ein Werk Erzbischof Wulfstans von York (Bern, 1959) no. 10. English translation in M. Swanton, Anglo-Saxon Prose (London, 1975) 125-38.

69 R. Morris (ed.), The Blickling Homilies of the Tenth Century (EETS OS) 58, 63, 73 (London, 1874-80, repr. in 1 vol., 1967) IV, 43-5.

70 D.A.E. Pelteret, 'Slavery in Anglo-Saxon England', in D.A.E. Pelteret and J.D. Woods (eds), The Anglo-Saxons: Synthesis and Achievement (Waterloo, Ont., 1985) 117-33.

71 All these examples to be found in J. Earle, A Hand-Book to the LandCharters, and Other Saxonic Documents (Oxford, 1888) 263, 264, 268 (sec. 4), 272 (secs 23, 26), 273 (sec. 27).

72 On the historical development of the degrees of chastity, see M. Bernards, Speculum Virginum: Geistigkeit und Seelenleben der Frau im Hochmittelalter (Vienna, 1952, repr. 1982) 40-51.

73 Bernards, Speculum Virginum, 42

74 Thorpe, Sermones Catholici, I, 'In Purificatione S. Mariae', 148, 11. 6-22; op. cit., I, 'De Assumptione Beatae Mariae', 446, 11. 30-448, 1. 3; op. cit, II, 'Dominica in Sexagesima', 92, 11. 32-94, 1. 17; Assmann, Angelsächsische Homilien, no. II, 'Letter to Sigefryth: Be bære halgan clænnysse', 11. 172-6.

75 Thorpe, Sermones Catholici, II, 'Dominica II: Post Aepiphania Domini', 70, 11. 16-24. the exegesis was quite common, cf. J. Hill, 'Elfric and Smaragdus', Anglo-Saxon England 21 (1992, 203-37) 223.

76 As, e.g. in Pope, Homilies of Elfric, II, no. XIX 'De Doctrina Apostolica', 70-89

77 Raith, Bussbuch, II, 20; Jost, Institutes of Polity, no. 17.

78 C. B. Fehr (ed.), Die Hirtenbriefe Alfrics in altenglischer und lateinischer Fassung (Hamburg, 1914); in Elfric's letter to Bishop Wulfsige (nr. I, 26-7) and in Ælfric's Old English Letter to Archbishop Wulfstan (nr. II, 156). In the latter letter, Ælfric seems to allow a remarriage to be blessed should the bride be a virgin.

79 Jost, Institutes of Polity, no. 17.

80 Thorpe, Sermones Catbolici, II, 'Dominica in Sexagesima', 94, 11. 11-13. On the church's concern for regulating the sexual life of the AngloSaxons, see two very informative articles, if presented somewhat contentiously, by A. Davies, 'Sexual Behaviour in Later Anglo-Saxon England', in E. Kooper (ed.), This Noble Craft ... Proceedings of the Xth Research Symposium of the Dutch and Belgian University Teachers of Old and Middle English and Historical Linguistics (Amsterdam and Atlanta, Ga., 1991) 83-105, and 'The Sexual Conversion of the AngloSaxons', in Dor, A Wyf there Was, 80-102.
WIDOWS IN ANGLO-SAXON ENGLAND

81 Assmann, Angelsächsische Homilien, no. II, 'Letter to Sigefryth', 11. $157-61$.

82 Earle, Hand-Book, 108-11.

83 B.J. Timmer (ed.), Judith (Exeter, 1978²).

84 S.J. Crawford (ed.), The Old English Version of the Heptateuch, Elfric's Treatise on the Old and New Testament and his Preface to Genesis(EETS OS) 160 (London, 1922) 48, 11. 772-80.

85 The latter two interpretations in Assmann, Angelsächsische Homilien, no. IX, 11. 410-39.

86 Jost, Institutes of Polity, no. 18.

87 Cf. Skeat, Alfric's Lives, I, no. XVIII, 'Sermo Excerptus de Librum Regum', 11. 65-71.

88 Cf. Skeat, Alfric's Lives, I, no. X, 'Cathedra S. Petri' 11. 53-79. Though Luke in Acts nowhere states explicitly that Dorcas (alias Tabitha) was a widow, Elfric does not hesitate to call her so in 11.54 and 77.

89 Thorpe, Sermones Catholici, I, 'Assumptio S. Iohannis Apostoli', 60, 11. 11-14.

90 Thorpe, Sermones Catholici, I, 'Passio Beati Laurentii Martyris', 418, 11. 18-22.

91 Skeat, Elfric's Lives, I, no. VI, 'Natale S. Mauri, Abbatis', 102-7; Thorpe, Sermones Catholici, II, 'Depositio S. Martini Episcopi', 508, 11. 8-13.

92 Thorpe, Sermones Catbolici, I, 'Natale S. Clementis Martyris', 566, 11. 4-27.

93 Thorpe, Sermones Catholici, II, 'Natale S. Stephani Protomartyris', 30. Elfric calls all fathers and mothers to take heed of her example and not to curse their children, at 34.

94 Skeat, Elfric's Lives, I, no. II, 'Natale S. Eugenie Virginis', 133-235.

95 Cf. P. Szarmach, 'Ælfric's Women Saints: Eugenia', in Damico and Olsen, New Readings, 146-57, at 151.

96 Gesta Herewardi, $397 \mathrm{f}$

97 P. Sims-Williams, Religion and Literature in Western England 600-800 (Cambridge, 1990) 160 and 166, respectively.

98 Sims-Williams, Religion, 223.

99 Sims-Williams, Religion, 131f.; 39, 174, respectively.

100 Förster, 'Die altenglische Beigaben', 328-35. The name Eormenburh is used erroneously here; see D.W. Rollason, The Mildrith Legend: A Study in Early Medieval Hagiography in England (Leicester, 1982) $39 \mathrm{f}$

101 N.E.S.A. Hamilton (ed.), Willelmi Malmesbiriensis Monachi 'De Gestis Pontificum Anglorum' (London, 1870) II, 87. I owe the precise reference to Elizabeth van Houts, cf. her 'Women and the Writing of History in the Early Middle Ages', Early Medieval Europe 1 (1992, 53-68) 68.

102 Thorpe, Sermones Catholici, II, 'Letania Maior. Feria Secunda', 324 11. 3-5.

103 Cf. C. Plummer (ed.), Bedae Venerabilis Historia Ecclesiastica Genti Anglorum, 2 vols (Oxford, 1896) II, 235.

104 H. Sauer (ed.), Theodulfi Capitula in England: Die altenglischen Übersetzungen, zusammen mit dem lateinischen Text (Munich, 1978) no. $44,399,11.17-19$. 
105 Skeat, Elfric's Lives, IV, no. XXXII, 11. 198-205.

106 Old Frisian law even provided for brides whose bridegrooms were killed

during the wedding festivities! If the bride followed the corpse to the graveyard and next proceeded to the groom's homestead, she would receive everything that was agreed upon in the wedding contract. The receive everything that was agreed upon in the wedding contract. The
young widow was then free to choose a new husband; see W.J. Buma and W. Ebel (eds), Das Fivelgoer Recht (Göttingen, 1972) XIV, 4. 